\title{
Communication
}

\section{TRIVIALISATION OF WOMEN'S SPORTS IN SRI LANKA: OVERCOMING INVISIBLE BARRIERS}

\section{Introduction}

Sport is an integral part of life in Sri Lanka. Participation in sport at local, regional, national and international level is a marker of the island's economic and socio-cultural development. Though not considered the island's national sport, cricket is perhaps the most popular sport and illuminates the passion of Sri Lankan contemporary culture (Roberts, 2009, p. 566). The "Cricket World Cup 2011" which was held in the sub continent (including Sri Lanka) fired the enthusiasm of all strata of society. A young child or an elderly person would have given the accurate answer 'Kumar Sangakkara' to the question "Who will captain the Sri Lankan national team for the 2011 Cricket World Cup?" just before the tournament began. However, it is rather disappointing to acknowledge the truth that those who can name all the players in the men's cricket national team would not even recognise the equivalent captain of the Sri Lankan women's cricket national team. Only a few individuals would perhaps remember that Shashikala Siriwardane led the Sri Lankan women's cricket national team in 2010 (Sri Lanka Cricket, 2010). Therefore, it is evident that women's participation in sports in Sri Lanka is not so well known. This idea is the basis for this paper, in which I have looked at

1. Patterns and issues relating to women's participation in sports in Sri Lanka from 1948, which is the era straight after gaining the independence from Britain

2. The benefits to Sri Lankan society in women participating in sport

3. The reasons for the current trivialisation of Sri Lankan women's sports, despite their contribution to sports at an international level

4. Ways to encourage Sri Lankan women to participate in sports 


\section{The Patterns And Issues Relating To Women's Participation in Sports in Sri Lanka from 1948}

Ancient Sri Lankan historical sources reveal that the formative roots of Sri Lankan women participating in sports extend as far back as the 12 th and $13^{\text {th }}$ Century B.C; for instance, it is stated in Sasandawatha, (Kumaratunga, 1963, p. 35), "Vamiyan pahala penda nuba nagena...." (When the ball, struck by the maidens, raises the sky). Also, in Thisara Vivwranava, "Lali kelana lada sonda liya..." (Fair maidens that sport with playing balls with their open tender palms ushering the colour of very new lotuses) (Kumaratunga, 1925, p. 73). What this demonstrates is that ancient Sri-Lankan women, determined to stay active, had spent their leisure time indulging in dance and folk games. However, differences in lifestyles and livelihoods at rural and urban settings, varying cultural strictures, and preference related to the permissible degree of women's sport and physical exercise has impacted on their participation in succeeding centuries.

Sri Lankan women's participation in sports did not significantly increase until after the late nineteen forties, the post-independence era. Prior to 1948, only a handful of women were provided the opportunity to compete in western sports such as basketball, netball and hockey. Women's participation in western sports in the 1940s was chiefly centralised within the Sri Lankan education system. Only the urban schools and those administered by either missionaries or other educators with western influence included physical education, games and dancing as part of the curricula or as leisure activities. Athletics and team games for both girls and boys were introduced and developed in these schools, too. Women outside missionary schools were not entitled to participate in the sports described above.

The social and political changes that occurred during the 1950s helped increased female athleticism. With the implementation of the "Nidahas advapana panatha" or the act for free education, the development of modern women's sports in Sri Lanka was given a boost. This legislation increased rural women's participation in sports by establishing Madya Maha Vidyala (Central schools)/ Consequently, western sports which were originally exclusive to women with high socioeconomic backgrounds were now made available for the middle and working classes. These increased opportunities throughout the entire education system empowered women through sports, in particular those from rural backgrounds. In addition, this approach awakened the holistic school system to include physical education into the curriculum and often conduct drill and games at an allocated time, even in schools situated in remote areas. 
Under Act no. 8, 1961, "Adara labana saha Abyasa Vidyala panatha" the Ministry of Education took control over some private schools thereby triggering redistribution of the federal money among rural schools (Ministry of Samurdhi, Youth and Sports, 1998, p. 103). This resulted in infrastructure investment and development in rural areas. Following these developments, teacher training colleges were established in Sri Lanka in the early part of the $20^{\text {th }}$ century and by 1950 s both male and female physical education teachers were specially trained in Saidapet (Madras) which contributed immensely in promoting games and athletics for both girls and boys in government and private schools. Other activities like Girl Guides and Boy Scout movements also contributed to encourage both physical activity and community service. Certain western sports such as netball, football and basketball etc, were included in the list of all island school sports festivals. Therefore, girls at school level in particular, were provided with ample opportunities to participate in drill squads, dance troops, volleyball, basketball, netball, hockey, badminton, tennis and table tennis. As a result, there was a noticeable increase in school girls' participation in sports in the rural areas. This trend was generated mainly as a result of increased opportunities to all sectors which at one point were limited to those who lived close to the capital city. This led women from all strata of society distinguishing themselves in sport; for instance, in 1962, Nirmala Dissanayake who was from a rural background gained the title of the first woman in Sri Lanka to record victory in an international sporting competition. She won the bronze medal for the 400 meter race in the 1962 Asian games in Jakarta. Ranjanie Jayasuriya also won a silver medal for Tennis (singles) in the same).

As a result of the education reforms in 1972, a practical component to Health and Physical Education was included in the NCGE exams (Ministry of Samurdhi, Youth and Sports, 1998, p. 104), and this further boosted women's participation in Sri Lankan sport competitions, particularly in athletics. Around 1980, barriers for females to participate in sports in rural areas were reduced even more because of the decentralisation of government funding for sports outside the capital Colombo via the establishment of school sports clubs and Colleges of Education. This opened the door for females living in rural areas and encouraged them to participate in sports that were mainly limited to Colombo previously. This enabled authorities to identify and improve the talents of rural participants like athlete Ramani Mangalika who studied in a rural school (Maha Vidyalaya) and won the gold medal in the $200 \mathrm{~m}$, while Simon Van Heer of Methodist College, Colombo won the gold medal for the $100 \mathrm{~m}$ at the $1^{\text {st }}$ South Asian Sports Competition (Ministry of Samurdhi, Youth and Sports, 1998, p. 124). 
In the 1980s and the1990s, the introduction of projects like the University Games, Mahaweli Games and Youth Games as well as the up-grading of School Athletic Games, were important turning points in Sri Lankan sports history for it provided females with the opportunity to excel in athletics. For example, the up-grading of the School Athletic Games in Sri-Lanka laid the foundation for women to participate in sports at an international level. Susanthika Jayasinghe, the female Olympic Bronze medallist, who was later awarded the Olympic silver medal after US athlete Marian Jones was found guilty of taking and illegal substance at the 2000 Sydney Olympic Games, is an example of such a female athlete whose talents were identified through the School Athletic Games scheme. This is the most prestigious award that a Sri Lanka woman has achieved in sport. Damayanthi Darsha is another female athlete who developed her skills through the School Athletic Games. She won a bronze medal in 1994 and two gold medals in 1998, at the Asian games; and a bronze medal at the Grand Prix Athletic Meet in 1999. Darsha was awarded the Duncan White award in 1999, the highest female Presidential sport award that is presented to female athletes in Sri Lanka.

The Ministry of Mahaweli development implemented the "Mahaweli Games" to enhance the social status of residents of the "Mahaweli Project." This enabled Mahaweli residents to improve their sporting abilities. Sriyani Kulawansa, a hurdler, was a gold medallist in the 1991 South Asian Games; a bronze medallist in the 1998 Asian Athletic Games; and a silver medallist at the Commonwealth Games. She also participated at an international level in Barcelona 1992, Sydney 2000, and at the 2004 Athens Olympic Games. This is a good example of a female athlete whose talents were identified through the "Mahaweli Games" Scheme (Ministry of Samurdhi, Youth and Sports, 1998).

\section{The Benefits of Women's Sport Participation to Sri Lankan Society}

Scientific evidence shows that sports and exercise are beneficial for the growth and development of young girls. They can have psychosocial, physical, behavioural and emotional benefits for females (Lopiano, 1994, p. 281). Women who are active in sports as girls feel greater confidence and pride in their physical and social selves than do women who are sedentary as kids). Therefore, the demand for women's sport has increased worldwide.

In the early history of the Olympic Games, women were not permitted to participate. Today, however, participation in Olympic sports by females has grown universally (Spears and Swanson, 1978, p. 4). Despite this increase, the global participation 
of women in sport differs. For instance, white western females with middle socioeconomic status often receive the required support from their families and communities to participate in sports, develop skills, aim for excellence and embrace physical fitness (Woods, 2007, p. 210). However, the opposite is true for women in some developing countries where they are generally discouraged and virtually excluded from participating in any sporting activity. There has been some increase in the participation of women involved in various sporting disciplines and a number of medals have been won by Sri Lankan women in international competitions since 1948, after independence from Britain. Despite this improvement, it is evident that women's participation in sports in Sri Lanka still requires major development. As a very supportive example, evidence reveals that despite Sri Lankan female atlletes being capable of winning a medal at the Olympics, a very low percentage of Sri Lankan females take part actively in sports. Furthermore, some female athletes have a negative perception of their participation due to their social status and living conditions. Globally. women's sports, at every competing level, attracts a large number of spectators; however, in Sri Lanka, women are not given the same importance as their counterparts across the globe.

\section{Reasons for the Current Trivialisation of Sri Lankan Women's Sports, Despite Their Contribution to Sports at an International Level}

Poverty is the main problem which confronts female sport participants in Sri Lanka. Sri Lanka suffered an ethnic conflict for three decades. This has resulted in an economic downturn. Malnutrition, the lack of health insurance, the violation of human rights and the non provision of social security continue to beset a country which also has to cope with a steadily increasing population; as a result, there is limited public expenditure on recreational activities. This means that both urban and rural women are obliged to prioritise survival. Such factors have created poor attitudes towards and perceptions on female involvement in sport.

The ethnic war directly influenced sport in Sri Lanka. The war destroyed social security and Sri Lankans did not have a chance to live in harmony. Women lost their husbands and sons. Some survived in fear and those who could afford it found a refuge abroad. Many who were regarded as the elite sport personnel in the island were pressurised into leaving the country which resulted in a "muscle drain." Those who stayed were emotionally exhausted and living under stress. For instance, the terrorist assassination of Minister Jeyaraj Fernandopulle also killed the former Olympic Marathon participant, K. A. 
Karunaratne and Lakshman de Silva, the National Athletic Coach. This incident led to growing concern among parents who restricted their children's participation in sports due to safety concerns.

Most of the female sport participants belong to teams based in their village or work place. One of the major problems caused by this is that teams are not under the patronage of major sport clubs. Therefore, genuine talent is not spotted by the relevant selection committees. Poor communication between the sport governing committees and sport clubs result in deserving individuals not being recognized which leads in turn to such people becoming demoralized.

For many women in Sri Lanka, cultural traditions, religion, and marriage must necessarily supersede their participation in sport which is why they have not had the opportunity to have a sporting career. Although men are still involved in sports even after marriage, females are required to look after their children and keep house. Not many men have allowed their wives to engage in sport and most women have to confront other barriers, too, in actively engaging in sport. The impact of religious attitudes has also had a negative influence; for example, many Muslim females are diffident in becoming involved in sports on account of perceived religious constraints.

The shortage of women coaches and inadequate training facilities for physical education teachers are also major problems in the Sri Lankan sports field. Moreover, most of the sports federations are dominated by males; therefore, all the decision making and officiating positions are held by males. Even though the world's first female prime minister was elected in Sri Lanka, Sri Lankan women's sport leadership rates are very low. This imbalance in power has grievously impacted on women's sport.

Most of the rural areas suffer from underutilisation of resources. They do not even possess basic facilities and infrastructure to enhance women's sport. Although the Sri Lankan government has provided some facilities through the ministry of sports, more play grounds, indoor stadiums and sport equipment for various sports are required. Even though some urban grounds are well maintained most of the rural and remote areas show lack of infrastructure. For example, some grounds are still unable to provide toilet or changing facilities. Such issues are especially detrimental to women's participation.

It is essential to introduce new technology to enhance sporting activities in the modern world. Unfortunately, Sri Lanka is at a very low level in using new technology within sport because the equipment is often unaffordable and there is a dearth of qualified technicians for application, maintenance and support. This lack impacts particular negatively on the participation of women in international athletic meets. Technological 
support from developed countries is especially required if women's sport is to be improved in Sri Lanka.

The media has an immense role to play in promoting women's sport. However, such promotion is an issue in Sri Lanka because of the lack of female sport media personnel. This discourages female sport participants as there is no person to champion their cause. Most of the female sport events are commented on by males which is not ideal. Females have the equal right to contribute to sports reporting through commentaries etc., but the authorities have done little to take affirmative action in this regard. Therefore, it is evident that opportunities for women to contribute to the development of women's sport needs to be improved.

\section{Ways to Encourage Sri Lankan Women's Participation in Sports}

There is a national sport competition exclusively for female participants in Sri Lanka but it only includes track and field. Despite its potential to enhance women's sports, this occasion by itself is not sufficient to remedy the deprivations suffered by women's in participating in sport. Therefore, this event should be revamped to include other sports that women can take part in and be conducted annually. This event would not only improve sport competency but also help to integrate different ethnic groups through sports.

A programme of professional development and education for sportswomen should be established. For example, workshops at a national level should be introduced to empower women's leadership roles among sport coaches, sport officers and physical education teachers. The workshops would also expand the technical knowledge of these personnel and sport participants. Furthermore, workshops for in-service physical education teachers should be established as well.

Another initiative that would benefit the development of Sri Lankan women's participation in sport would be to establish an inaugural programme that enhances sport activities among mothers and elderly women and encourage their involvement. To enable this to happen it is essential to recruit more female coaches, sport officers, media personnel and PE teachers and to establish a network of sport women personnel. Finally, it is most important to set up a child care programme to assist sporting women. This would help them to find the time to attend training and coaching sessions. A child care programme would be of particular benefit to disadvantaged and rural women as they are the least likely to have the resources to pay for child care on their own. 